\title{
Roles of Floral Organs and Phytohormones in Flower Stalk Elongation of Cymbidium (Orchidaceae)
}

\author{
Hajime Ohno and Syunji Kako* \\ School of Agriculture, Nagoya University, Chikusa, Nagoya 464-01
}

\begin{abstract}
Summary
Effects of floral organs and phytohormones on the flower stalk elongation were investigated using a miniature Cymbidium hybrid (C. $\times$ Sazanami 'Haru-no-umi'). Complete excision of flower buds from an inflorescence greatly inhibited the elongation of the flower stalk (peduncle). When the basal two-thirds of flower buds on an inflorescence were removed, the flower stalk elongated nearly to the length of an intact peduncle. On the contrary, when the distal flower buds were excised, the upper part of the peduncle did not elongate. The elongation was also greatly reduced by removal of anthers alone or the entire perianths.

Under high temperature conditions that induce blasting of flower buds, $\beta$-naphthaleneacetic acid (NAA) stimulated flower stalk elongation whether flower buds did or did not set. NAA also reversed the cessation of peduncle elongation caused by anther excision. However, this treatment did not promote flower opening. The application of gibberellic acid $\left(\mathrm{GA}_{3}\right)$ stimulated both peduncle elongation and flower bud development, but the treatment failed to restore the elongation of peduncles from which flower buds were excised. These findings suggest that the peduncle elongation is stimulated mainly by auxin supplied from developing flower buds, especially from the anthers, and that flower bud development is primarily caused by gibberellin (GA). The elongation of the stalk is a secondary effect of developing floral parts brought about by GA.
\end{abstract}

\section{Introduction}

Cymbidium orchids grown under high temperatures during the early stages of flower development are damaged by blasting of flower buds $(8,9,10)$. This physiological disorder is characterized by poor flower bud development and reduced elongation of flower stalks.

It is well known that developing flower buds or floral organs participate in the growth of flower stalks $(7,13)$. For example, the elongation of flower stalks is reduced by decapitation in tulip $(5,12)$, daffodil $(4,5)$ and gerbera (14). In tulip, the removal of the perianth and/or gynostemium inhibits the elongation of the last internode of the stalk $(5,12)$. Auxins and/or gibberellins (GAs) were also reported to influence the growth of flower stalks or scapes $(7,13)$. The reduced elongation of

Received for publication 28 June 1990. Parts of this study were presented at the Spring Meetings (1974, 1977 ) and the Autumn Meetings $(1975,1976)$ of the Japanese Society for Horticultural Science.

*Present address: Faculty of Agriculture, Yamaguchi University, Yamaguchi 753. decapitated flower stalks in tulip was reversed by the application of indole-3-acetic acid (IAA) or NAA $(5,12)$. Similar effects of IAA were shown for daffodil $(4,5)$. In gerbera, the stunting effect of decapitation of the scape was reversed by the combined application of IAA and $\mathrm{GA}_{3}$ (14).

In this paper, effects of excising different floral organs with and without applications of auxin and GA on flower stalk elongation and flower bud development of miniature Cymbidium hybrid plants were examined.

\section{Materials and Methods}

Plant materials: Plants of miniature Cymbidium hybrid $(C . \times$ Sazanami 'Haru-no-umi') were grown at $20^{\circ} \mathrm{C}$ or below as described elsewhere (10). Plants with an uniform size of inflorescence were selected and used in the following experiments.

Removals of flower buds and floral organs: The cultivar used in the present experiments usually set about 20 flower buds per inflorescence. The flower buds on the stalk longer than $9 \mathrm{~cm}$, which were non-susceptible to the blasting (9), were 
divided into three groups of the upper (U), middle $(\mathrm{M})$ and the lower (L) ones according to their position. The upper two $(U+M)$ or lower two $(M+L)$ groups of flower buds or all flower buds $(\mathrm{U}+\mathrm{M}+\mathrm{L})$ were excised with tweezers. In excising floral organs, folded perianths of the flower buds were carefully unfolded with tweezers, then the sepals, petals, lip, and anther were removed separately or in the combination. When anthers were removed through longitudinal slits made in the abaxial sides of flower buds, the control flower buds had longitudinal slits made.

Treatments with phytohormones: Forty and 50 ppm solutions of NAA, IAA, and $\mathrm{GA}_{3}$ were made by dissolving the hormones in distilled water. The flower buds susceptible to the blasting and/or flower stalks were sprayed with the phytohormone solutions through a longitudinal slit made along the mid-vein of the bracts. Flower buds, nonsusceptible to blasting, situated on well-developed inflorescences were also treated with NAA after their anthers were removed. In this case, NAA was applied as lanolin paste $(0,100$, or $500 \mathrm{ppm}$ NAA solution: lanolin; $2: 3, \mathrm{~V} / \mathrm{V}$ ) to the emasculated sites of flower buds. Treated plants were grown at high temperatures, unless noted otherwise.

\section{Results}

The effect of flower bud excision on the flower stalk elongation is shown in Fig. 1. Removal of all flower buds $(\mathrm{U}+\mathrm{M}+\mathrm{L})$ greatly reduced the length of flower stalks. The elongation of flower stalks was also reduced by the removal of the upper two groups $(U+M)$ of flower buds; growth inhibition was restricted only to the part of the stalks where the flower buds were excised. On the contrary, removal of flower buds from the $\mathrm{M}+\mathrm{L}$ regions had a slight influence on elongation of the flower stalks. The entire flower stalks were relatively well elongated, regardless of whether the flower buds were removed or left intact. The elongation of the lower part of the peduncle bearing several bracts was less affected by the excision of flower buds.

Excision of flower parts had a pronounced effect on peduncle elongation (Fig. 2). Removal of all perianths noticeably reduced the length of the flower stalk, but removal of only the outer perianths had little effect. The excision of anthers

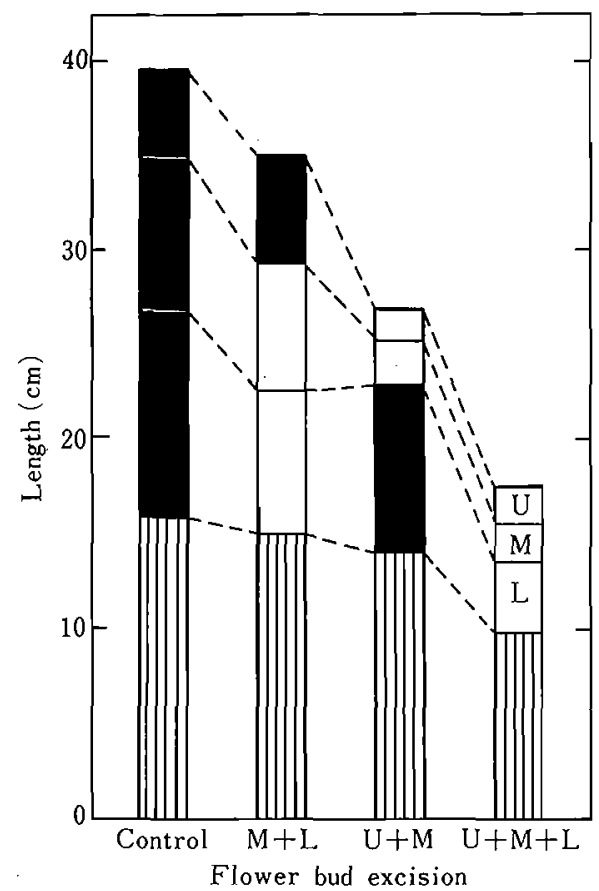

Fig. 1. Effect of flower bud excision on the flower stalk elongation. Flower buds were divided into three groups: Upper (U), middle $(\mathrm{M})$ and lower $(\mathrm{L})$ according to the position on the flower stalk. The lower two groups $(M+L)$, the upper two groups $(U+M)$ or all three groups $(U+M+L)$ of flower buds were removed. The experiment was conducted under high temperatures $\left(30^{\circ} \mathrm{C}\right.$ day $/ 25^{\circ} \mathrm{C}$ night $)$. $m$, the part of flower stalk bearing flower buds; $\square$, the flower bud-excised part of flower stalk; $\square$, the part of flower stalk below the lowest flower bud. The numbers of inflorescences used in the control, $M+L, U+M$ and $U+M+L$ excision were $5,6,9$ and 5 , respectively.

alone resulted in a dramatic reduction of stalk length. The effect of excision of the perianths or anthers was similar to that of complete removal of flower buds.

Flower bud development and anthesis were also influenced by the excision of floral organs (Table 1). Anther excision caused blasting of all flower buds, whereas excision of the outer perianths, lip or inner perianths prevented some intact flower buds from opening but a considerable number did reach anthesis.

The application of $50 \mathrm{ppm}$ NAA to flower buds stimulated the elongation of flower stalks in inflorescences which were cultured under low temperatures, then transferred to high temperatures after the treatment (Fig. 3). Flower buds treated 


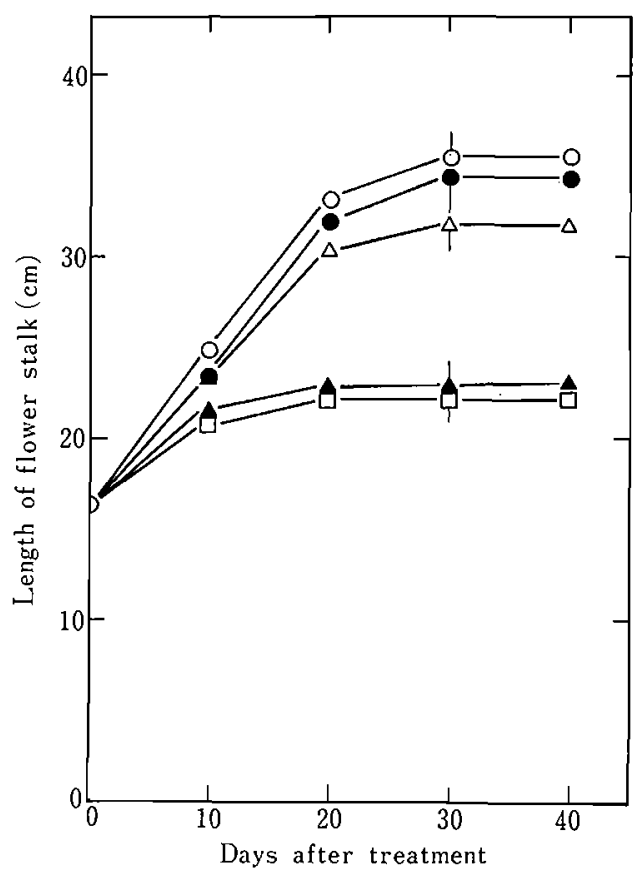

Fig. 2. Effect of floral organ excision on the flower stalk elongation. Plants grown under low temperatures $\left(5-20^{\circ} \mathrm{C}\right)$ in a glasshouse were used. Anthers were excised through a slit made in the abaxial side of the flower buds. Excised floral organs were as follows; none (control, 0 ), slit only without emasculation $(\bullet)$, outer perianths $(\triangle)$, all perianths $(\Delta)$, or anthers ( $\square$ ). Treated plants were placed under the same conditions as before treatment. Vertical bars indicate standard errors $(n=4$ to 6$)$.

Table 1. Effect of removing floral parts on the flowering of Cymbidium plants maintained at low temperatures.

\begin{tabular}{|c|c|c|c|c|}
\hline \multirow{2}{*}{ Excision } & \multicolumn{3}{|c|}{ No. of flower buds } & \multirow{2}{*}{$\begin{array}{c}\text { Flowering } \\
(\%)\end{array}$} \\
\hline & Opened & Blasted & Total & \\
\hline None (Control) & 51 & 15 & 66 & 77 \\
\hline Outer perianths & 34 & 44 & 78 & 44 \\
\hline Lip & 35 & 36 & 71 & 49 \\
\hline Inner perianths & 12 & 68 & 80 & 15 \\
\hline Anther & 0 & 69 & 69 & 0 \\
\hline
\end{tabular}

with NAA became blasted after enlarging to different degrees, but remained in attached to the stalk. Flower buds in the control also became blasted but they dropped.

The application of lanolin paste containing 100 or $500 \mathrm{ppm} \mathrm{NAA} \mathrm{to} \mathrm{the} \mathrm{emasculated} \mathrm{flower} \mathrm{buds}$

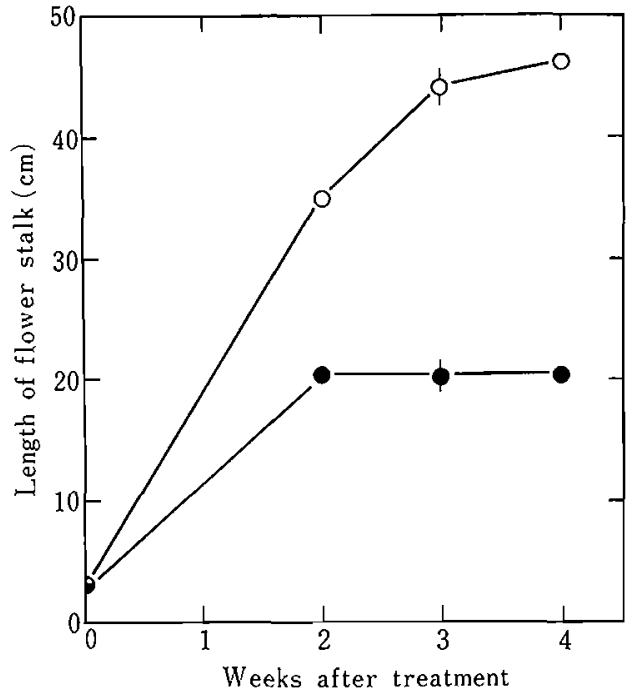

Fig. 3. Stimulation of flower stalk elongation by NAA. Plants grown at the low temperatures $\left(5-20^{\circ} \mathrm{C}\right)$ were transferred to high temperatures $\left(30^{\circ} \mathrm{C}\right.$ day $/ 25^{\circ} \mathrm{C}$ night), then the flower buds were sprayed with $0(\bullet)$ or $50(0)$ ppm NAA solution. Vertical bars indicate standard errors $(n=7)$.

reversed the suppressive effect of anther removal (Fig. 4). However, NAA treatment caused all developing flower buds to become blasted.

The application of $40 \mathrm{ppm} \mathrm{GA}_{3}$ enhanced flower stalk elongation and stimulated the perianth (flower bud) growth (Fig. 5). More than $60 \%$ of flower buds treated with $\mathrm{GA}_{3}$ developed to anthesis (Table 2). This stimulation of perianth growth was not observed in flower stalks elongated by auxin.

As both NAA and $\mathrm{GA}_{3}$ stimulated flower stalk elongation, the next target was fixed on the effect of these phytohormones to flower stalk elongation in flower bud-excised inflorescences. In such inflorescences, a tremendous difference was observed between those treated with NAA and $\mathrm{GA}_{3}$ and then grown under both high and low temperatures (Fig. 6). NAA induced stalk elongation similar to that of intact inflorescences, whereas $\mathrm{GA}_{3}$ did not stimulate growth without the presence of flower buds. IAA also showed the positive effect to the elongation, but its effect was less than that of NAA (data not shown).

\section{Discussion}

Excision of flower buds was demonstrated to 
Table 2. Promotive effect of $\mathrm{GA}_{3\}}$ on the flowering of Cymbidium plants inhibited by high temperatures. Plants were grown under low temperatures and transferred to high temperatures at which time flower buds were treated with $40 \mathrm{ppm} \mathrm{GA}_{33}$.

\begin{tabular}{|c|c|c|c|c|c|c|c|}
\hline \multirow{2}{*}{ Treatment } & \multirow{2}{*}{$\begin{array}{l}\text { No. of inflores- } \\
\text { cences }\end{array}$} & \multicolumn{2}{|c|}{ Length of flower stalk $(\mathrm{cm})^{z}$} & \multicolumn{3}{|c|}{ No. of flower buds } & \multirow{2}{*}{$\begin{array}{c}\text { Flowering } \\
(\%)\end{array}$} \\
\hline & & Initial & Final & Opened & Blasted & Total & \\
\hline Control & 10 & $3.9 \pm 0.1$ & $13.4 \pm 2.0$ & 5 & 226 & 231 & 2 \\
\hline $\mathrm{GA}_{3}$ & 10 & $3.9 \pm 0.1$ & $41.9 \pm 1.6$ & 154 & 79 & 233 & 66 \\
\hline
\end{tabular}

"Mean \pm standard error.

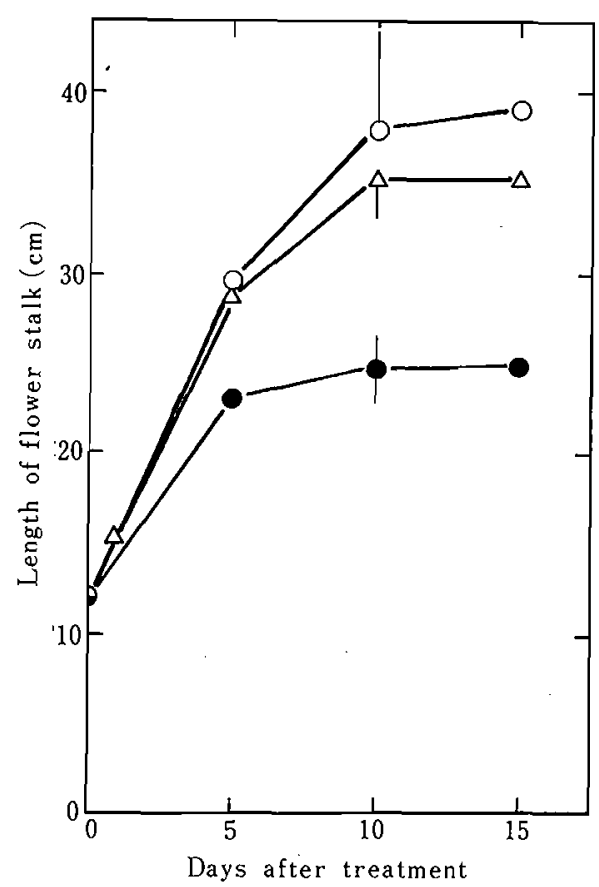

Fig. 4. The elongation of flower stalks by NAA applied to emasculated flower buds. Plants grown at low temperatures were transferred to high temperatures, then the anther was removed from each flower bud. Emasculated flower buds were treated with lanolin paste containing $0(\bullet), 100(\Delta)$ or 500 (०) ppm NAA solution. Vertical bars indicate standard errors $(n=5)$.

reduce flower stalk elongation, especially in those plants which set terminal flowers on peduncles $(4,5,12)$ or on capitulum (14). The treatment holds true for the miniature Cymbidium hybrid which forms racemes with about 20 flower buds per peduncle (Fig 1). The development of the lower group of flower buds did not stimulate the elongation of the zone of the peduncle where the flower buds were excised. On the contrary, the presence of the upper group of flower buds stimulated the

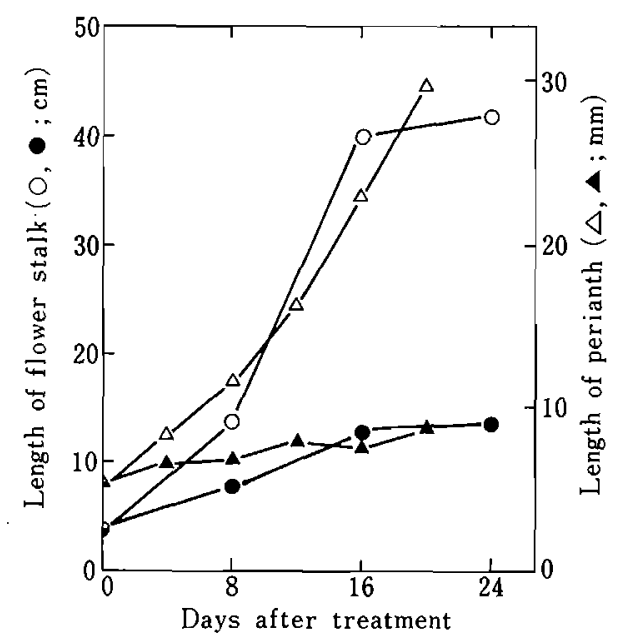

Fig. 5. Effects of $\mathrm{GA}_{3}$ on flower stalk elongation and flower bud development. Plants grown under low temperatures were transferred to high temperatures, then the flower buds were sprayed with $40 \mathrm{ppm} \mathrm{GA}$ (open symbols) or distilled water (closed symbols). Ten inflorescences were used in each treatment.

elongation of the lower part of the stalk from which flower buds were excised. Such a basipetal effect controlled by flower buds is suggestive of polar transport of auxin.

By excising different floral organs, the anther was found to be the most influential for flower stalk elongation of Cymbidium (Fig. 2), differing from the excision of the gynostemium of daffodil $(4,5)$, or gynostemium and perianths of tulip $(5,12)$. Emasculated Cymbidium flower buds became blasted even at low temperatures (Table 1), indicating that the growth of the anther is important for the development of the rest of the flower buds on the stalk. Under high temperature conditions, microsporogenesis in the anther failed to proceed into meiotic cell differentiation resulting in 


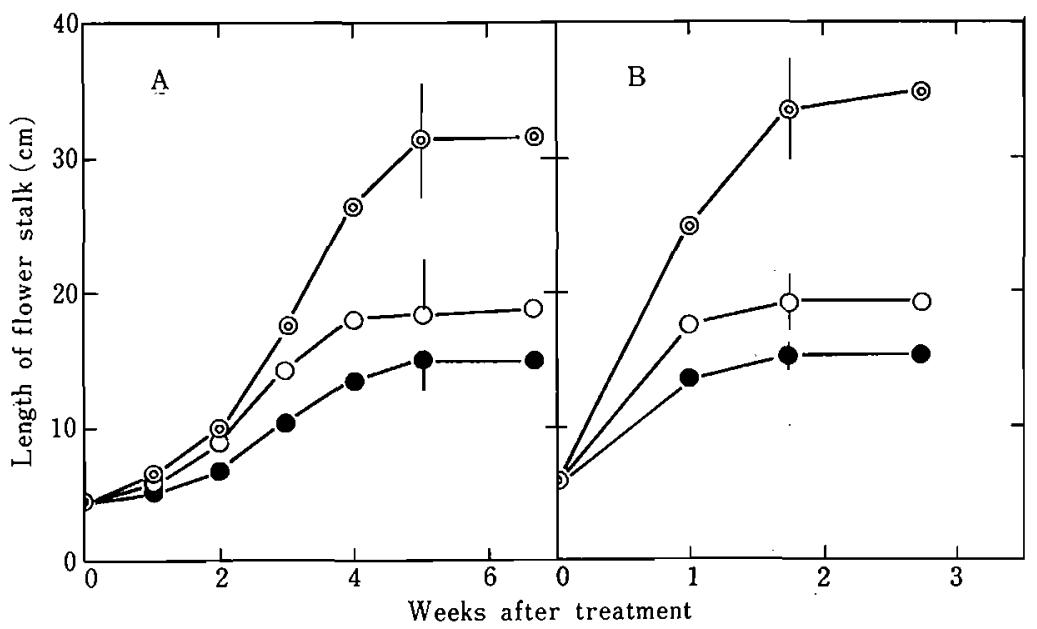

Fig. 6. Different effect between NAA and $\mathrm{GA}_{3}$ on the elongation of flower bud-excised stalks. All flower buds were excised from the inflorescences, then the flower stalks were treated with $40 \mathrm{ppm}$ NAA (O), $40 \mathrm{ppm} \mathrm{GA}_{3}(0)$ or distilled water $(\bullet)$. Treated plants were transferred to low temperatures $\left(18^{\circ} \mathrm{C}\right.$ day $/ 13^{\circ} \mathrm{C}$ night, A) or high temperatures $(B)$. Vertical bars indicate standard errors $(\mathrm{n}=7)$.

the degradation of future meiocytes $(8,10)$. Thus, the blasting of flower buds without concurrent elongation of the flower stalk is attributed to disordered pollen development.

When perianths were completely excised, the flower buds developed symptoms similar to those of emasculated buds (Fig. 2). This may be attributed to the desiccation of the column or to the loss of protection against light by removal of perianths. We come to this conclusion because a considerable number of flower buds developed to anthesis when only outer or inner perianths were excised (Table 1). The wounding caused by the excision of perianths may be associated with the blasting of flower buds.

Auxin is known to move basipetally and stimulate the elongation of decapitated flower stalks in several plants such as tulip $(5,12)$, daffodil $(4,5)$ and gerbera (14). In Cymbidium, the application of NAA also promoted flower stalk elongation even under high temperature conditions (Fig. 3). Further, it stimulated the elongation of flower stalks which was arrested by emasculation (Fig. 4). However, NAA didn't completely restore flower bud development and failed to prohibit flower buds from becoming blasted. From the above results, we postulate that the elongation of flower stalks is stimulated by auxin secreted from the anther, but that development of flower buds needs additional factors that are synthesized and exported from the anther. The failure of flower bud development may originate from the evolution of ethylene induced by auxin. Ethylene is apt to cause blasting of flower buds $(2,6)$ and wilting of flowers $(1)$.

$\mathrm{GA}_{3}$ induces flower stalk elongation of Cymbidium when plants are transferred to high temperatures (Fig. 5). This GA effect indicates that GA is required for normal development of flower buds, which in turn, supplies auxins needed for the elongation of the flower stalk. This concept is supported by the finding that $\mathrm{GA}_{3}$ was less effective in elongating peduncles without flower buds (Fig. 6). Such weak influence by $\mathrm{GA}_{3}$ was also demonstrated in the case of decapitated flower stalks form tulip $(5,12)$ or daffodil $(4,5)$. In gerbera, $\mathrm{GA}_{3}$ was also effective for stalk elongation but less effective than was IAA (14). Okubo et al. (11) demonstrated that the inhibitory effect of ancymidol on the growth of tulip flower stalk was overcome by the application of $\mathrm{GA}_{3}$. Our results (Fig. 5) suggest that GA is the major limiting factor for flower bud development and flower stalk elongation when plants are transferred to high temperatures. But because NAA reverses the growth inhibition of Cymbidium stalks caused by the excision of flower buds which $\mathrm{GA}_{3}$ does not (Fig. 6), auxin is be- 
lieved to play a major role in the elongation process. This phytohormone is supplied from flower buds whose development is stimulated by $\mathrm{GA}_{3}$, or by low temperature. The supply of auxin by the developing flower buds was also noted in other plants $(3,7,13)$. The effectiveness of GA on flower stalk elongation is different among plant species. The difference may depend on the stage of flower stalk development. That is, "the major effect of GA is apparently on the 'youngest' cells, whereas auxin has a greater effect on older tissues" (14).

Thus, we consider the failure of flower stalk elongation in miniature Cymbidium hybrid plants cultured under high temperature to be caused by the reduction or cessation of auxin production in flower buds and its limited export to the peduncle.

\section{Acknowledgements}

The authors are grateful to Prof. S. Yamaki for his critical reading of the manuscript and valuable suggestions, and to Mr. K. Sakakibara for his cultural assistance.

\section{Literature Cited}

1. Abeles, F.B. 1973. Ethylene in plant biology. Academic Press, New York.

2. De Munk, W.J. 1973 Flower-bud blasting in tulips caused by ethylene. Neth. J. Pl. Path. $79: 41-53$.

3. Edelbluth, E. and H. Kaldewey. 1976. Auxin in scapes, flower buds, flowers and fruits of daffodil (Narcissus pseudonarcissus L,). Planta 131 : 285-291.

4. Hanks, G. R. and A.R. Rees. 1975. Scape elongation in narcissus: the influence of floral organs.
New Phytol. 75 : 605-612.

5. Hanks, G.R. and A.R. Rees. 1977. Stem elongation in tulip and narcissus: The influence of floral organs and growth regulators. New Phytol. $78: 579-591$.

6. Kamerbeek, G.A. and W. J. De Munk. 1976. A review of ethylene effects in bulbous plants. Scientia Hortic. 4 : 101-115.

7. Lang, A. 1961. Auxin in flowering. p.909-950. In: W. Ruhland (ed.). Encyclopedia of plant physiology. Vol. XIV. Springer Verlag, Berlin.

8. Ohno, H. 1991. Microsporogenesis and flower bud blasting affected by high temperature and gibberellic acid in Cymbidium (Orchidaceae). J. Japan. Soc. Hort. Sci. 60 : 149-156.

9. Ohno, H. and S. Kako. 1978. Development of inflorescences in Cymbidium (Orchidaceae). I. Difference in temperature effects depending on the developmental stage of inflorescences. Environ. Control in Biol. 16:73-80.

10. Ohno, H. and S. Kako. 1978. Development of inflorescences in Cymbidium (Orchidaceae). II. An estimation of critical and abortive stages for the effect of high temperature. Environ. Control in Biol. 16:81-91.

11. Okubo, H., S. Shiraishi and S. Uemoto. 1986. Factors controlling elongation of the last internode in tulip flower stalk. J. Japan. Soc. Hort. Sci. $55: 320-325$.

12. Op Den Kelder, P., M. Benschop and A.A. De Hertogh. 1971. Factors affecting floral stalk elongation of flowering tulips. J. Amer. Soc. Hort. Sci. $96: 603-605$.

13. Sachs, R.M. 1965. Stem elongation. Ann. Rev. Plant Physiol. 16:73-96.

14. Sachs, R.M. 1968. Control of intercalary growth in the scape of gerbera by auxin and gibberellic acid. Amer. J. Bot. $55: 62-68$. 
シンビジウムの花荃伸長における花器官および植物ホルモンの役割について

\author{
大野 始 - 加古舜治* \\ 名古屋大学塀学部 464-01 名古屋市千種区不老叮
}

\begin{abstract}
摘要
小型シンビジウムの交配種サザナミ‘ハルノウミ’の が, NAA 処理により花らいの有無に関係なく花茎伸長 花茎伸長における花器官および植物ホルモンの役割を 明らかにするため，花器官の除去や生唇調節物質処理 の花菱伸長に及ぼす影響を調べた。全花らいを除去す ると花荃伸長は著しく抑制された。花らいのうち，花 茎基部側の 3 分の 2 を除去しても花茎伸長はほとんど 影㐩を受けなかったが，先端側の 3 分の 2 を除去する と、花らいを除去した部分の伸長が著しく抑制された。 全花らいからやくだけを除去しても，全花らいを除去 した場合と同様，花茎は伸長しなくなった，全花らい から花被をすべて除去しても同様の結果が得られた。 「花飛び」現橡を起こす高温条件では花茎は伸長しない が新起された。やく除去部へNAA 処理しても同様の 効果が得られた. NAA 処理では，いずれの場合も花ら いは開花に至らなかった。 $\mathrm{GA}_{3}$ 処理は花茥伸長と花らい の発育・開花のいずれをも誘起したが, $\mathrm{GA}_{3}$ の花茎伸長 作用は花らいを除去した花蕉では見られなかった。こ れらの結果から、シンビジウムの花茎伸長には発育中 の花らいによって供給されるオーキシンが主として関 与しており，花らいの発育や花荃伸長にとってやくが 特に重要な器官であることや, $\mathrm{GA}_{3}$ が直接花茎伸長を誘 起するのではなく，花らいを正常に発育させることに より花荎を伸長させていることが示された。
\end{abstract}

*現在：山口大学堐学部。 